\title{
Going It Alone Won't Work! The Relational Imperative for Social Innovation in Social Enterprises
}

\author{
Wendy Phillips ${ }^{1}$ Elizabeth A. Alexander ${ }^{2} \cdot$ Hazel Lee $^{3}$
}

Received: 19 December 2016/Accepted: 13 June 2017/Published online: 23 June 2017

(c) The Author(s) 2017. This article is an open access publication

\begin{abstract}
Shifts in the philosophy of the "state" and a growing emphasis on the "Big Society" have placed an increasing onus on a newly emerging organizational form, social enterprises, to deliver innovative solutions to ease societal issues. However, the question of how social enterprises manage the process of social innovation remains largely unexplored. Based on insights from both in-depth interviews and a quantitative empirical study of social enterprises, this research examines the role of stakeholder relationships in supporting the process of social innovation within social enterprises. We find that social enterprises are adept at working with their stakeholders in the ideation stage of social innovation. In contrast, they often fail to harness knowledge and expertise from their partners during the social innovation implementation phase. Consequently, we propose a social innovationstakeholder relationship matrix that provides social enterprises in particular with insight for developing stakeholder relationships to achieve their social innovation missions.
\end{abstract}

Elizabeth A. Alexander

Elizabeth.alexander@ncl.ac.uk

Wendy Phillips

Wendy.Phillips@uwe.ac.uk

Hazel Lee

hazelsy.lee@polyu.edu.hk

1 Bristol Business School, University of the West of England, Frenchay Campus, Bristol BS16 1QY, UK

2 Newcastle University Business School, 5 Barrack Road, Newcastle-upon-Tyne NE1 4SE, UK

3 Department of Management and Marketing, M1032 Li Ka Shing Tower, The Hong Kong Polytechnic University, Hung Hom, Kowloon, Hong Kong
Keywords Social innovation - Social enterprises · Stakeholder relationships · Empirical

\section{Introduction}

In recent years, we have witnessed a profound shift in how a range of societal needs are being addressed, giving rise to the concept of social innovation. Social innovation is defined as "a novel solution to a social problem that is more effective, efficient, or just than existing solutions and for which the value created accrues primarily to society as a whole rather than private individuals" (Phills et al. 2008, p. 39). Social innovation offers novel ways of addressing unmet social needs, often through the rise of new organizational forms such as social enterprises (EU 2014). Discussion of a "third way" as an alternative for delivering social welfare in the UK provides a political and sociological context that favors the emergence of both social enterprise organizations and social innovation (Phillips and Smith 2014). It also suggests an important role for stakeholder engagement and cooperation in the process of value creation (Freeman et al. 2010) reflecting as it does a shift toward a rethinking of the relationships between business and society. For clarity, we adopt the definition of a social enterprise as "a business with primarily social objectives whose surpluses are principally reinvested for that purpose in the business or in the community, rather than being driven by the need to maximize profit for shareholders and owners" (BIS 2011, p. 2). This definition resonates with Freeman et al.'s (2010) work on stakeholder theory since social enterprises embody a stakeholder orientation to their operations, relying on jointness of interests with a range of stakeholders through which to collaboratively achieve their 
goals while seeking reinvestment in their communities, and thus rejecting a profit motive for their actions.

As a consequence of the agenda promoting links between the public sector, civil society and the private sector, the UK has witnessed a dramatic increase in the formal role of these social enterprises with almost one-third operating in the most deprived communities, seeking to effect change and address social need (Social Enterprise UK 2015). Increasingly, the links of social enterprises to economic and social programs are being recognized as playing a central role in social innovation (OECD 2011). Against this backdrop, there has been growing interest in the area of social innovation (Cajaiba-Santana 2014; Dees 2008; Mulgan 2006; Nicholls and Murdock 2012; van der Have and Rubalcaba 2016). However, while we know from extant research about processes for business and technological innovation, we know very little about the practice of social innovation (Murray et al. 2009; Mulgan et al. 2007; van der Have and Rubalcaba, 2016).

Cajaiba-Santana (2014) calls for a new paradigm arguing social innovation is substantially different to technological innovation since it centers on creating new social structures. In this research, we aim to make a theoretical contribution to the literature on social innovation by examining one particular feature of the problem-how organizations such as social enterprises utilize stakeholder relationships to identify opportunities for, and to facilitate, social innovation. Our view of stakeholder contributions to the social innovation process draws on work by Post et al. (2002, p. 7) that emphasizes the importance of multiple stakeholder relationships as "the ultimate sources of organizational wealth" and the salience of stakeholders for joint value creation (Freeman et al. 2010). Strand and Freeman $(2015$, p. 80$)$ suggest that through pursuing cooperative advantage an organization "implements a value creating strategy based on cooperating with its stakeholders that results in superior value creation for the company and its stakeholders." Importantly, Bridoux and Stoelhorst (2016) argue that stakeholder relationships can contribute to creating value, especially when these relationships are based on shared common beliefs in addressing needs in contrast to when their actions are driven by selfinterested, market transaction motives.

Given the public policy agenda in many countries is increasingly placing an emphasis on social innovation in the third sector to deliver social change (EU 2014), addressing this question has not only theoretical value but practical significance to further enhance social innovation opportunities. Such opportunities include those met by social enterprises themselves, as well as by foundations, governments and corporations seeking to further their social value creation agendas (Post et al. 2002; Freeman et al. 2010). This paper draws on research from in-depth interviews and a large-scale survey with managers in social enterprises in the UK. It provides unique insights into current practices and recommendations for managers to achieve their goal of delivering on the promise of social innovation, focusing on resource and capability development and the building of stakeholder relationships. The contexts within which these social enterprises operate vary, but all recognize the importance of fostering stakeholder relationships as a means of capturing emerging innovative opportunities and developing the capabilities required to implement these opportunities.

Our paper begins by reviewing the literature on social enterprises and social innovation, drawing upon existing models of innovation to establish the framework for our study. We develop our theoretical arguments that collaborative relational linkages provide mechanisms for mobilizing joint interests of stakeholders as substitute or complementary resources critical to social innovation. Next, we outline our research context, methods and results. Drawing on our survey and in-depth interview findings, we shed light on how social enterprises undertake social innovation. Finally, we discuss the implications of our research and propose a social innovation-relationships matrix as a strategic tool that can be applied not just by practitioners in social enterprises but also, more broadly, to those mainstream corporations aiming to foster their cooperative posture and develop their engagement in social innovation.

\section{Social Enterprises and Social Innovation}

The importance of social innovation is highlighted by the OECD (2011, p. 20) as responses to unsolved or inadequately met social problems and needs that have been unsuccessfully addressed by the government or the commercial market such as "identifying and delivering new services that improve the quality of life of individuals and communities; identifying and implementing new labor market integration processes, new competencies, new jobs, and new forms of participation" in the workplace. At its core, and a crucial distinction from business innovation driven by market forces, social innovation contains a socioeconomic and cultural dimension focusing on social change to fill gaps in provision that neither the state nor the private sector has been able to identify or to close (Mulgan 2006; Lettice and Parekh 2010).

Social innovation occurs across several forms of organization from those for-profit firms that seek to create social value, to dual mission organizations that form new hybrid models, such as the Benefit Corporation, Low-Profit Limited Liability Company (L3C), and Flexible Purpose Corporation in the USA (Battilana et al. 2012), to NGOs 
and charities. Social enterprises lie along this continuum or "hybridity spectrum" (Dees and Anderson 2006). Through adopting a business approach, social enterprises focus on bringing about improved social outcomes for a particular community or group of stakeholders (Chell 2007).

According to Social Enterprise UK (2015), nearly twothirds of social enterprises are actively engaged in some form of innovation, having introduced a new or improved product or service in the preceding year. Hence, social enterprises represent an important organizational form through which to examine the process of social innovation. However, the duality of integrating market mechanisms with strategies to create both social and economic values (Alter 2007; Emerson and Twersky 1996) sets up specific challenges in delivering the social innovation agenda. These challenges are further compounded because social enterprises face challenging operating environments characterized by insecure resources, reliance on non-traditional employment channels and volunteers, and uncertain funding sources (Moore et al. 2012). Inconsistencies in resource flows require social enterprises to frequently reassess their resource configurations, particularly in the pursuit of social innovation. To survive over the long term, social enterprises need to develop a repertoire of approaches that enables them to create, extend and modify their activities in response to shifting landscapes, actively seeking to work jointly with their stakeholders in efforts to identify and develop innovation opportunities (Social Enterprise UK 2015).

\section{Stakeholders and Relationships for Developing Social Innovation Capabilities}

Over the past decade, social innovation has emerged as a field of study (van der Have and Rubalcaba 2016) that has focused primarily on defining the concept through both theoretical contributions and case studies. A survey of extant literature by Murray et al. (2009) identified a lack of widely shared concepts, thorough histories, comparative research or quantitative analyses. Given the growing importance of social innovation (OECD 2011), a review of the literature reveals a remarkable dearth of research into the process of social innovation (Phillips et al. 2015); consequently, we draw on a range of the mainstream innovation as well as the emergent social innovation literatures as the basis for developing our hypotheses.

A contribution by Chalmers and Balan-Vnuk (2013) highlights this gap in research on social innovation and argues that while much attention has been paid to innovation in for-profit firms, especially in hi-tech industries, the approach to social innovation will be markedly different: crucially, the type of organizations enacting social innovation is resource-constrained and the process itself will be less clear because social innovation is a different, more amorphous phenomenon than product innovation. Despite the potential "messiness" of social innovation, Nicholls and Murdock (2012) argue the pursuit of social innovation can be broken down in broad terms into two distinct phases: the process of generating new ideas and the process of implementation to create successful practice.

Prior research into the ideation process in social innovation has tended to focus on the role of social entrepreneurs in recognizing an opportunity and pursuing a social mission (Monllor and Attaran 2008; De Bruin and Ferrante 2011; Phillips et al. 2015). Work on the idea formation process by Murphy and Coombes (2009) emphasizes the relational dimension in the mobilization of economic, social and environmental resources as a precondition for the emergence of social innovation. They contend the mobilization process is manifestly different to traditional patterns of discovery by entrepreneurial firms as it primarily involves substantial volunteerism and public support of the social issue at hand. Importantly, they contend that such social resources provide a flow of knowledge and information critical to the innovation process. Some of this knowledge will reside within the social enterprise, but much of it is likely to lie across a range of stakeholders, and thus requires substantial relationship building to identify and access it.

The extant literature on open innovation (Chesbrough 2003; West and Bogers 2014) provides relevant insights for social innovation through emphasizing external resources that potentially create value for the organization but that are not owned by the organization. Such resources include volunteers, innovation communities, ecosystems and the wider surrounding networks. Open innovation harnesses collective creativity by utilizing "purposive inflows and outflows of knowledge to accelerate internal innovation, and expand the markets for external use of innovation, respectively" (Chesbrough et al. 2006, p. 1). Further, the concept of open innovation is predicated on the assumption that organizations can manage the flows of knowledge across organizational boundaries to both search for opportunities from a range of stakeholders and transfer knowledge into the organization, as well create routines and mechanisms to integrate knowledge and build competencies (Chesbrough 2003).

The challenges in managing the process of developing and assimilating knowledge for innovation highlight the increasing shift toward inter-organizational networking, moving away from operating and innovating in isolation (Bessant 2003; Birkinshaw et al. 2007) —a theme echoed in research on social innovation. For example, Lyon's (2012) multiple case study of services to the unemployed found networks and stakeholder relationships between social enterprises and organizations in the private and public 
sectors were important to enabling social enterprises to develop their activities and enhance their social innovation impact. Likewise, Westley et al. (2014) highlight the need for social enterprises to build resource configurations, including sets of complex skills geared toward mobilizing resources, as central to their ability to implement social innovation. Further, because intangible forms of capital flow across organizational and community boundaries developing stakeholder relationships could assist in the cross-fertilization of ideas and co-creation of user-driven innovation (Edwards-Schachter et al. 2012).

Chalmers and Balan-Vnuk (2013) seek to address the lacunae of research into social innovation through case studies investigating the role of routines and the development of absorptive capacity of nonprofit organizations to identify and develop opportunities for social innovation, especially through utilizing user knowledge. They identified a range of routines employed to identify knowledge and learning and to transfer this into the organization, including maintaining contact with their communities to obtain valuable user information, debriefing field workers, capturing client feedback, training, attending conferences, and collaborating with more technically proficient stakeholders such as universities or other experts.

While the opportunity recognition process differs due to the different context and nature of social innovation, the emergence of new approaches and new organizational forms through which to address social issues has also been evident. Recent work highlights the role of stakeholders in developing value-creating activities through business model innovation (Zott et al. 2011). This includes new models for achieving social objectives (Lyon and Fernandez 2012; Seelos and Mair 2007), leveraging capabilities of NGOs through cross-sectoral partnerships (Dahan et al. 2010) and collaborative partnerships between corporations and NGOs (Manning and Roessler 2014; Nicholls and Huybrechts 2016), including a focus on enhancing the capabilities of stakeholders (Garriga 2014).

Business model innovation can be based on novel designs, or new ways in which an organization chooses to engage with stakeholders to create value for all exchange partners through "connecting previously unconnected parties, by linking transaction participants in new ways, or by designing new transaction mechanisms" (Zott and Amit 2007, p. 184). While focused on for-profit entrepreneurial firms, we can learn from Zott and Amit's (2007, p. 195) work on noveltycentered designs, as they appear to contribute to innovation even under conditions of resource scarcity such as that confronting the majority of social enterprises through "harnessing" the resources of stakeholders. This is important since in a volatile environment, an organization may form multiple linkages with stakeholders to compensate for its resource constraints (Hung and Chou 2013). As with the entrepreneurial firms studied by Zott and Amit (2007), so social enterprises are dependent upon building business model designs that enable them to effectively integrate across multiple stakeholder groups and organizations in ways not previously done in order to achieve their social innovation objectives. Such business models have resonance for social enterprises as they may lead to new market creation or may indeed evolve in order to develop new processes, evident in research on hybrid organizations (Battilana et al. 2012; Battilana and Dorado 2010). However, a major difference between the business models discussed by Zott et al. (2011) and those adopted by social enterprises is that they are not based on a pure economic exchange mechanism but, instead, frequently rely on non-market or relational linkages (Post et al. 2002), and this makes their management and governance all the more complex.

Utilizing a range of stakeholder linkages for learning becomes a vital process for social enterprises, and through adapting their structures and their strategic search activities, social enterprises are more able to fully develop valuable knowledge that resides across networks (Chalmers 2013). This is all the more important in the pursuit of social innovation since social innovation spans across multiple sectoral, community and organizational boundaries rather than residing in a single class, such that failure to access appropriate stakeholder networks severely impairs social innovation (Lettice and Parekh 2010). As Freeman et al. (2010, p. 281) note, "value is not "discovered" lying around in the market, but created through shared assumptions and beliefs in a community." Similarly, Roloff (2008) emphasizes the importance of multi-stakeholder networks in addressing complex social problems. Such networks focus on adopting issue-based stakeholder approaches to ensure the, often contradictory, needs of different stakeholders are addressed as opposed to organization-focused approaches that simply consider the welfare of the organization (Roloff 2008). Issue-based stakeholder management is particularly appropriate in addressing societal issues where there is a need to represent members of society that are often marginalized or overlooked (Roloff 2008).

Building on this prior literature, we propose social enterprises can develop stakeholder relationships that support the identification of new opportunities and access to prospective new markets or stakeholders. They can also develop stakeholder relationships to enhance their knowledge or skills base to assist in building capabilities to implement social innovation. We discuss each in turn.

\section{Stakeholder Relationships for Opportunity Identification}

Social enterprises engage with stakeholders to move beyond traditional markets and sectors and support the 
development of opportunities that enable them to utilize their capabilities in different contexts through four broad mechanisms.

First stakeholders can help provide access to new markets. It can often be challenging to understand and access new markets (Chalmers 2013), particularly when dealing with social opportunities that may not have a clearly defined customer base or a recognizable market demand. So, through developing stakeholder linkages social enterprises will be able to acquire a better understanding of social innovation opportunities and how to serve them. Associated with this, social enterprises develop relationships and social structures across a diverse range of prospective new stakeholders, such as public agencies, major think tanks, universities and governmental institutions. Building relationships with these new stakeholders provides a means of accessing important information regarding innovation opportunities (Lettice and Parekh 2010). Identifying potential stakeholders that are often unconnected with an organization's specialist service or product can assist in generating new ideas to transfer across industry sectors and apply in new ways. Further, social innovation can arise from accessing new communities through developing relationships with, for instance, local support groups or community action groups. These groups can provide a sandpit for idea and opportunity generation and can also ensure the social enterprise develops social innovations that really incorporate the needs of its target community and so contribute to the mobilization process (Murphy and Coombes 2009). Finally, stakeholder relationships can support the pursuit of new opportunities through sharing risk, especially through partnering with like-minded organizations that embody similar values. For instance, organizations that intend to deliver social benefits at a local level may find other local organizations willing to partner with them in order to deliver benefits to their community (Dahan et al. 2010).

Drawing on the prior literature and applying the insights concerning the importance of relational linkages to the innovation process, we propose that where the social enterprise invests in building its relationships with a range of stakeholders it will enhance its ability to recognize social innovation opportunities that ally with its current set of capabilities. Formally,

Hypothesis 1 Stakeholder linkages for identifying innovation opportunities by social enterprises are positively associated with social innovation.

\section{Stakeholder Relationships to Develop Capabilities for Implementation}

Stakeholders provide social enterprises with the ability to develop their capabilities to implement social innovation through three main mechanisms. First, social enterprises should be able to develop knowledge through stakeholder relationships that expose the organization to new knowledge bases such as technical knowledge and research from universities and research bodies, as well as from wider networking groups (Lyon 2012; Westley et al. 2014). Second, social enterprises should be able to utilize opportunities of its stakeholder network relationships to build expertise to fill a resource gap. This can include nonmarket relationships such as staff secondments, mentoring schemes, internships, placements and work exchange programs or, in some instances, pro bono work from larger organizations (Chalmers and Balan-Vnuk 2013). Finally, social enterprises should be able to develop new skills through building stakeholder relationships that can enhance its internal skills base through working with training and support agencies or individuals capable of offering these services (Chalmers and Balan-Vnuk 2013).

The set of stakeholder relationship mechanisms that enable the social enterprise to implement social innovation opportunities may require different sets of relational skills than those associated with identifying opportunities that its existing resources can implement. The nature of the relationships aimed at supporting implementation relates to resource acquisition and enhancement and represents a greater commitment on behalf of stakeholders involved in the relationship. To the extent social enterprises can develop these relationships, the literature suggests they should be able to develop new sets of resources that will enhance their ability to implement social innovation.

Hypothesis 2 Stakeholder linkages for building capabilities to implement innovation opportunities by social enterprises are positively associated with social innovation.

Finally, as noted previously, the innovation literature suggests that firms that engage formally with others outside their organization are more likely to develop innovations than those who undertake the innovation from internal processes in isolation (Chesbrough 2003; West and Bogers 2014). This applies to both the search for new opportunities and capabilities currently outside the organization's set of skills or resources (Lyon 2012; Chalmers and Balan-Vnuk 2013). Due to the tacit nature of building capabilities (Dyer and Singh 1998) through stakeholder relationships, social enterprises are more likely to develop their learning from working jointly with stakeholders while co-creating social innovation (Edwards-Schachter et al. 2012). In contrast, attempting to achieve their goals only by working through stakeholders entails a more arm's-length relationship to achieve social innovation by relying on the skills, competences and resources of the partner to undertake the innovation. Consequently, working through stakeholders as 
partners is less likely to result in an inward transfer of knowledge and skills for the social enterprise.

Hypothesis 3a Stakeholder linkages for building opportunity identification relationships are associated with undertaking innovation activities in conjunction with partners as well as through partners rather than in isolation.

Hypothesis 3b Stakeholder linkages for building implementation relationships are associated with undertaking innovation activities in conjunction with partners rather than either in isolation or than through partners.

\section{Data and Methodology}

We designed our empirical approach utilizing mixed methods of a survey targeting top management team members in social enterprises across the UK supported with semi-structured interviews.

\section{Survey and Sample}

In developing our survey instrument, we drew on an expert panel of academics and professionals representing the social enterprise community and used these to pilot a questionnaire. The questionnaire sought information about the organization, including its age, size, and geographic scope, as well as information on its social innovation and stakeholder relationships. The sample was derived from membership of a national body that has wide coverage of social enterprises in the UK and upon whose website we launched our survey. Individuals were invited to respond to the survey in a two-stage process, first by e-mail and then through a process of telephone calls; 262 responses were received. The web-based survey provided an IP address tracking function that assisted in preventing multiple responses. Respondents were asked to provide their name, a contact method and the name of their social enterprise. We triangulated responses by cross-checking core data with publically available sources on social enterprise websites and with the Charities Commission. The survey resulted in 211 responses for which organizations had been in operation for over one year and provided full information.

\section{Qualitative Data}

In our qualitative study, we conducted 31 semi-structured interviews each lasting up to $1 \mathrm{~h}$ and analyzed using NVivo. The sample is a random selection of 80 respondents who completed the online survey and who had indicated willingness for further contact. We concluded the interview process at 31 because we were converging on saturation around the key themes (Williams and Lewis 2005). The interview sample is representative of the survey respondents in terms of sectors, firm size and age. The interview protocol contained semi-structured questions to explore the broad themes of how stakeholder relationships influence the process of social innovation as well as access to sources of knowledge and skills. We analyzed these data using the key themes from the literature and present these findings following our discussion of the survey measures and statistical models below.

\section{Statistical Model Measures}

\section{Dependent Variable}

Our dependent variable for hypotheses 1 and 2 is a measure of social innovation based on accepted practice in the European Community Innovation Survey (CIS). The CIS is conducted in the UK by the Department for Business Innovation and Skills to investigate the level of innovative activity in firms and to gain an understanding of the contributing factors and constraints to innovation. We included our definition of social innovation and, drawing on our expert panel, adapted the questions to a social enterprise and social innovation context to capture the type of social innovation activity. We utilized standard measures of whether the innovation was new to the world or new to the organization (Booz Allen and Hamilton 1982) and measure social innovation as a scale where the highest score is innovation that is new to the world-defined following the CIS as "this enterprise engaged in an innovation activity before any other organization."

For hypothesis 3, we followed the CIS methodology and sought information about the contribution of the social enterprise in developing the social innovation. The CIS asks respondents to indicate sources of innovation as mainly by this business or enterprise group, this business with other businesses or organizations, and other businesses or organizations. Drawing on this established methodology, we asked whether innovation had been developed by the enterprise itself in isolation or in conjunction with partners, or whether indeed the innovation occurred mainly through partners.

\section{Independent Variables}

Our survey requested information about the motives for developing stakeholder relationships for social innovation and respondents were asked to indicate which they utilized (see below). We subjected the responses to categorical principal components analysis in SPSS demonstrating two relevant dimensions with an eigenvalue greater than one, as required for each (Meulman and Heiser 2011). The items 
loaded as expected onto the two proposed dimensions: "Opportunity Identification" comprises relationships for accessing new markets, new communities and new stakeholders, and sharing risk (Chronbach's alpha .75), while the dimension representing "Implementation" represents a distinct contrast with high component loadings on developing skills, knowledge and expertise (Chronbach's alpha $.81)$.

\section{Control Variables}

To control for systemic differences between firms based on observable characteristics, we employed a series of controls. Age of the social enterprise may affect a social enterprise's ability to develop longer term and more productive relationships and to build resources and capabilities for innovation. We lagged the model by using employment and turnover data from the prior year to capture the effects of size on social innovation activities. Models were run with dummy variables for geographical location (compared to social enterprises operating across multiple regions as the default). We included dummy variables for industry sector (business services and marketing; environment, renewables and energy; education and youth services; health and social care; employment services; retail and leisure; housing; and financial services) but found that industry was nonsignificant so do not include this in the final models. Finally, we include a dummy variable to indicate whether the social enterprise is classed as a "social firm," a specific category that has a particular remit to employ the disadvantaged and that might affect the results (Ducci et al. 2002).

\section{Model Results}

The correlations between independent variables, as given in Table 1, are all below the threshold of 0.7 with the only significant and high correlation occurring between employment and turnover. To estimate the models for hypotheses 1 and 2, the degree to which social innovation occurs as a result of stakeholder relationships, we conducted a regression analysis (Field 2009). We examined the results and found no issues with respect to the regression model assumptions based on visual inspections of the residual plots, linearity and independence of error terms (Hair et al. 1998). The largest Variance Inflation Factor stood at 1.9 for turnover with all Condition Indices under 10, the highest being 6.7 between employment and turnover, indicating no concerns for multi-collinearity (Belsley 1991).

Table 2 presents the results of the regression analyses used for testing hypotheses 1 and 2. Model 1 includes the control variables only, and Model 2 incorporates the independent variables. The results reveal that the stakeholder relationships associated with opportunity identification are positively and significantly associated with innovation $(B=0.27 ; p<.01)$, thus supporting hypothesis 1. In contrast, relationships geared toward building capabilities for implementation are not significant $(B=0.11$, $p>.05$ ), and as such hypothesis 2 is not supported.

To test hypotheses $3 \mathrm{a}$ and $3 \mathrm{~b}$, comparing the effects of stakeholder relationships on the categories of how innovation occurs, we use multinomial logistic regression (Field 2009). This model enables us to detect the degree to which stakeholder relationships are associated with enabling innovation to be undertaken mainly by the social enterprise itself, a mix of the social enterprise with its partners, or mainly through partners. The results, as listed in Table 3, indicate that innovation is more likely to occur in conjunction with partners compared to by the social enterprise in isolation for both opportunity identification $(B=1.45, \quad p<.01)$ and implementation $(B=1.32$, $p<.01)$ relationships. The same is true for innovation undertaken through partners compared to by the social enterprise in isolation for both opportunity identification $(B=6.79, p<.01)$ and for implementation $(B=3.07$, $p<.05)$ relationships. Finally, innovation is more likely to occur mainly through partners compared to in conjunction with partners for opportunity identification $(B=5.34$, $p<.05$ ), whereas there is no significant difference for implementation $(B=1.74, p>.05)$. Overall, the results support hypotheses $3 \mathrm{a}$ and $3 \mathrm{~b}$ of the importance of building stakeholder relationships as a means to develop social innovation.

\section{Qualitative results}

In this section, we present our interview findings to elaborate upon issues in the social innovation process. We utilized NVivo to analyze the interview transcripts and present a summary of the findings in Table 4 and elaborate on these below.

Opportunity identification for social innovation is clearly seen as an outcome from forming multiple stakeholder linkages. Several CEOs of social enterprises identified the importance of networking, as one pointed out "[we] network quite extensively, and understand what's going on...in the context in which we're working...making sure that we're aware of the changing environment." Another CEO explained the significance of networking for social innovation,

to generate...innovative ideas,...to test concepts that we're developing,... and indeed....at the other end around direct delivery of solutions. Most of the 
Table 1 Correlation matrix

\begin{tabular}{|c|c|c|c|c|c|c|c|c|c|c|c|c|c|c|c|c|}
\hline & & 1 & 2 & 3 & 4 & 5 & 6 & 7 & 8 & 9 & 10 & 11 & 12 & 13 & 14 & 15 \\
\hline 1 & Social firm & & & & & & & & & & & & & & & \\
\hline 2 & Midlands & .01 & & & & & & & & & & & & & & \\
\hline 3 & West & .05 & .10 & & & & & & & & & & & & & \\
\hline 4 & East & .08 & .12 & .11 & & & & & & & & & & & & \\
\hline 5 & London & .06 & .11 & .10 & .122 & & & & & & & & & & & \\
\hline 6 & $\mathrm{~N}$. Ireland & .07 & .05 & .05 & .06 & .06 & & & & & & & & & & \\
\hline 7 & Scotland & $.17^{\mathrm{a}}$ & .11 & .10 & .12 & .11 & .06 & & & & & & & & & \\
\hline 8 & Wales & .09 & .08 & .07 & .07 & .08 & .04 & .08 & & & & & & & & \\
\hline 9 & North East & .02 & .09 & .08 & .10 & .09 & .05 & .09 & .063 & & & & & & & \\
\hline 10 & North West & .03 & .11 & .10 & .12 & .11 & .06 & .11 & .06 & .09 & & & & & & \\
\hline 11 & Yorkshire/Humberside & $.14^{\mathrm{a}}$ & .08 & .07 & .09 & .08 & .04 & .08 & .06 & .06 & .08 & & & & & \\
\hline 12 & Age & .04 & .10 & $.19^{\mathrm{a}}$ & .06 & .01 & .06 & .04 & .02 & .13 & .03 & .01 & & & & \\
\hline 13 & Employment & .12 & .07 & .00 & .12 & .00 & .09 & .09 & .02 & .04 & .12 & .06 & $.25^{\mathrm{a}}$ & & & \\
\hline 14 & Turnover & .12 & .06 & .04 & .07 & $.13^{\mathrm{a}}$ & .11 & .08 & .04 & .01 & .05 & .06 & $.31^{\mathrm{a}}$ & $.64^{\mathrm{a}}$ & & \\
\hline 15 & Opportunity Identification Relationships & .05 & .05 & .03 & .01 & .02 & .05 & .12 & .06 & .04 & .09 & .06 & .01 & .09 & .06 & \\
\hline 16 & Implementation Relationships & .03 & .13 & .05 & .06 & .07 & .08 & $.16^{\mathrm{a}}$ & .03 & .01 & .05 & .08 & .11 & .09 & .06 & .04 \\
\hline
\end{tabular}

${ }^{a}$ Correlation significant at the 0.05 level (two-tailed)

Table 2 Regression-relationships for social innovation

\begin{tabular}{lcc}
\hline Predictor & Model 1 & Model 2 \\
\hline Constant & $3.04^{* * *}$ & $3.03^{* * *}$ \\
Social firm & 0.05 & 0.05 \\
Midlands & $-0.56^{*}$ & $-0.54^{*}$ \\
West of England & $-1.07^{* * *}$ & $-1.03^{* * *}$ \\
East of England & $-0.65^{* *}$ & $-0.67^{* *}$ \\
London & -0.08 & -0.12 \\
Northern Ireland & $-0.91^{*}$ & $-0.99^{*}$ \\
Scotland & -0.39 & -0.39 \\
Wales & $-0.67^{*}$ & $-0.65 \dagger$ \\
North East of England & $-1.05^{* *}$ & $-1.08^{* * *}$ \\
North West of England & $-0.55^{*}$ & $-0.60^{*}$ \\
Yorkshire and Humberside & $-0.69^{*}$ & $-0.71^{*}$ \\
Age & 0.35 & 0.30 \\
Total employment & -0.12 & -0.16 \\
Turnover & 0.01 & 0.01 \\
Opportunity Identification relationships & & $0.27^{* *}$ \\
Implementation relationships & & 0.11 \\
Model total $R^{2} .175 ; \Delta R^{2}$ & $.143^{*}$ & $.032^{*}$ \\
\hline
\end{tabular}

Omitted variable for comparison of regions is "Operate across multiple regions." Results for controls on industry sectors are nonsignificant in both models and for clarity are not included in this table ${ }^{\dagger} p<.10 ; * p<.05 ; * * p<.01 ; * * * p<.001$

resources for innovation [are] about networks, about relationships with the right individuals...engagement with other areas that generate the thinking.
A number of organizations commented on stakeholder relationships acting as a means through which to develop market knowledge and, through developing such relationships with larger organizations that have established marketing capabilities, social enterprises are better able to access new markets. One social enterprise revealed it actively seeks to engage with a wide range of organizations to generate new ideas for social innovation. Likewise, another CEO noted that even as a larger social enterprise it is "more able to manage the innovation at the delivery...in terms of scoping what we're going to, that's where we rely more on others."

Building stakeholder relationships to access new markets also involves formal linkages, including utilizing collaboration opportunities via their boards as this example highlights,

one of the advantages now of broadening our board...there's much better scope for [market] scanning, and because we all have very different...interests and very different experiences and areas of specialism,...we're scanning a much broader area than we ever were before, because there's more of us to bring that information in and...things that perhaps would not have been spotted before...there's only so much observing of the external market that one person can do.

In another example, we find members of the social enterprise develop their personal networks to access new communities. For instance, one of our interviewees noted, 
Table 3 Multinomial logistic regression-how stakeholder relationships contribute to the process of social innovation

\begin{tabular}{llll}
\hline Relationship focus & $\begin{array}{l}\text { Innovation in conjunction with partners } \\
\text { compared to mainly by self }\end{array}$ & $\begin{array}{l}\text { Innovation mainly through partners } \\
\text { compared to mainly by self }\end{array}$ & $\begin{array}{l}\text { Innovation mainly through partners } \\
\text { compared to with partners }\end{array}$ \\
\hline $\begin{array}{l}\text { Opportunity } \\
\begin{array}{l}\text { Identification } \\
\text { relationships }\end{array}\end{array}$ & $1.45^{* *}$ & $6.79^{* *}$ & $5.34^{*}$ \\
$\begin{array}{l}\text { Implementation } \\
\text { relationships }\end{array}$ & $1.32^{* *}$ & & 1.74 \\
\hline
\end{tabular}

$R^{2} .331$ (Cox \& Snell), .39 (Nagelkerke). Model $\chi^{2} p<.001$. Coefficients are shown at $* p<.05 ; * * p<.01$

there are no formal networks...but I'm on the board of the local neighborhood partnership, it's a very active one so I get to know an awful lot of what goes on in the community...that kind of networking and ever expanding network, you get to learn...who you need to ask, who's doing what, what organizations might be doing something.

Such connections involving groups directly related to the social enterprise's activities not only provide information but also influence the direction in which the social enterprise seeks opportunities and validates its actions,

we do have an advisory council with key stakeholders from the community, so we have young people on it and parents, and volunteers and a member of staff...somebody from schools, GP...people who are in our world. And that advisory council feed into the board...that challenges the board to think in different ways.

Social enterprises often face a challenging moral dilemma associated with the social imperative that drives every aspect of their activities-how to manage resources and constraints and the trade-offs between the need to pursue and develop innovative opportunities against addressing and dealing with societal needs. One CEO pointed out that traditional networking or relationshipbuilding activities, such as attending conferences and events, routinely undertaken by many commercial organizations, may conflict with a social enterprise's social objectives, since,

$£ 300$ for me to go to a conference could be $£ 300$ that's spent on an offender getting part-time work with us for a month or something. So...can I justify the value in going to an event...or would I be better off talking to one of the speakers directly?

As a result, social enterprises often adopt innovative and low-cost approaches to networking, relying on social media, free events and, in some cases, free-riding, as a means of overcoming financial constraints and avoiding moral qualms of divesting funds away from support of their social mission. In particular, social enterprises tend to rely on their personal networks and engaging with stakeholders directly, as this interviewee highlights,

I don't do that many conferences, I'm much more...one-to-one networking...the teacup or the mug is more my weapon of choice. It's going to get to know people one to one...try to get to know the right people and then maintain relationships...working through them to other networks and finding out things that way, rather than conferences or indeed pay market analysts.

For many organizations, opportunity identification is impeded by resource constraints that give rise to insurmountable risk by going it alone, as a senior member of a social enterprise explained, "you support one another and encourage one another and do things together! That's a very successful way of growing."

Implementation appears to be a difficult proposition for many organizations as one CEO highlighted, "there's a gap still in the business side of it, we're very good at getting the opportunity, but we're not so good at...sustaining the business stream." Stakeholder relationships that provide social enterprises with exposure to and support the development of new knowledge are especially important when social enterprises attempt to develop capabilities to implement their social innovation efforts,

I think for innovation, most of the resources for innovation largely is about networks...about relationships with the right individuals and the engagement with other areas that generate the thinking. So I think innovation is mainly about people...for the delivery or the development of innovative ideas into delivery.

Some of this knowledge will come from relationships with others in the same sector as this interviewee noted, "my experience is that organizations in the same industry are very important so we can understand, we can learn from [them]." 
Table 4 Stakeholder relationship dimensions for social innovation

\begin{tabular}{|c|c|c|}
\hline Criteria & Description & Examples \\
\hline
\end{tabular}

Opportunity Identification

Access new markets

Relationships that enable social enterprises to understand and access new market segments

Access new stakeholders

Relationships with prospective key stakeholders such as public agencies, major think tanks, universities and governmental institutions

Access new communities

Relationships that support access to local communities through, for instance, local support groups or community action groups

Share risk

\section{Implementation}

Develop knowledge

Build expertise

Develop new skills

Relationships that can support the development of new skills

Relationships that expose the social enterprise to new knowledge

Relationships that can provide expertise within the social enterprise often via volunteers and pro bono work from larger private organizations
If there is one big gap I think most...have got, is the ability to market test... we never had to do it before...we're not quite sure how to do it

We need all the tools of a commercial organization, and one of the things is very obviously lacking, is our marketing and communications ability...but we're learning. We're getting there slowly

We've actively tried to engage with bodies [that] have very little do with what we do...that's really important as a way of generating new ways of looking at things. If we were looking at criminal justice for example...I'm not likely to find much innovation if all I' $m$ doing is talking to prisoners in the probation service

It's really about keeping ourselves at the forefront of the waste and energy environment industries in the social sector...local businesses...national businesses

Working with local people can provide...[innovation]...some of the large agencies, the people with the money...they can be an environment for innovation

A lot of it is through networking, going to meetings, talk to people...we work with an infrastructural organization called [who] basically provide assistance to start up community groups for charities

I think a bit of courage, networking, sharing the exposure to risk with others...sharing the load and sharing the risk, and sharing the venture...you know you don't make as much money

We worked for a local health service to get funding for some gym equipment, and then we worked with a different individual who provided the gym activities in the gym.... and to maintain it as a sustainable activity, working with an individual that's got a specific interest in gym equipment was invaluable

In terms of proof of concept... what's important there would be things like access to research, so...bodies like universities and think tanks become very useful

We seek expertise through... [organization] and networking groups. We also will go to similar organizations

We met the chief executive of [Company], he has offered some of us...mentorship....and also somebody...to work within our company for free...from their business team. I think that would really help us

They're not paid consultants, but they're experienced in their fields, it's just...people that have worked in business who are giving their time freely

To run an organization on volunteers is a very tricky thing so we're....after volunteers and or trustees with these skills...[using these relationships]

If I was looking for support, you'd be looking at the intermediary organizations who've delivered training and support 
A major problem highlighted through the interviews is "finding people and resources in terms of the proof of concept and the marketization, scaling-up element." One director pointed to stakeholder relationships bringing in "the kind of expertise and experience and services that are needed to complement what we do...if we're going to be truly effective...we need to have other organizations involved," testifying to the importance of jointness of interests for value creation.

Interviewees indicated they actively seek expertise from other organizations to implement social innovations, as they are acutely aware of the need to seek expertise in areas outside of their "normal area of working." We found that social enterprises attempt to build expertise within the organization through a range of mechanisms including technical skills and knowledge or research from institutions such as universities, as conveyed by one CEO, "where we lack expertise we seek it, experience and expertise in other organizations; so we work with universities...maybe technical, or it may be research based." Thus, they actively try and engage stakeholders to build expertise within the social enterprise often via consultants, volunteers, secondments and pro bono work from larger private organizations,

we absolutely do need people with specialist knowledge, we would be never able to have that in house...for certain projects we are $100 \%$ reliant on accessing outside help, if we can do that on reduced cost or no cost through sort of people either finding pro bono expertise support or volunteering, fantastic!

As one representative of a social enterprises noted, they had an offer of mentorship and support from individuals in a for-profit corporation that they felt "would really help."

Given that social enterprises are hybrid organizations that need to combine a business approach while meeting social needs, it was significant that our interviewees highlighted they are internally challenged by the requirement of commercial proficiencies in order to sustain their social innovation focus. In particular, social enterprises highlighted skills gaps around generic management issues such as leadership, finance and marketing-related skills as one interviewee commented,

we've got a lot of training courses currently to develop the leadership skills of the managers because they have been asked to take on more responsibility, more activity as part of growing, so obviously we need to support them in that transition.

Social enterprises revealed they sought to gain generic, non-sector-specific skills to address this resource gap mainly from the public sector via business support agencies. For more specific skill needs required to implement social innovation projects, social enterprises seek to build relationships with consultants and other social entrepreneurs or organizations from the same industry. One of our interviewees highlighted that in the,

implementation stage, it's about really honing in on what skills we can use off people... and outsourcing particular skills rather than developing the skills in-house through training which could use up valuable resources that could be allocated elsewhere....and...looking at general consultancy firms... it wouldn't be an advantage for us to spend time...on building those skills, it would make more sense to bring someone on board for that certain project who can help.

Further, some social enterprises assist others by providing low-cost services to smaller social enterprises, this CEO explains,

they're only one centre... so they can't afford to have the specialist support like finance directors, marketing directors like we have. We're using our technical specialists to provide services to them.

Increasingly social enterprises are shifting their focus and more actively seeking to develop strong stakeholder relationships in the private sector through which to develop more appropriate skills, knowledge and business capabilities.

\section{General Discussion}

Our study sets out to understand the relational practices and processes through which social innovation occurs. Since social enterprises are closely aligned to their constituent communities, we proposed they would develop stakeholder relational linkages that would help identify social needs not addressed through markets or public provision. Hence, we expected to find that developing stakeholder relationships to access new markets, communities and stakeholders as well as share risk, would be positively aligned with social innovation. We found this to be so for the ability to identify opportunities that align with current capabilities in the social enterprise. In contrast, although social enterprises sought to utilize their stakeholder relationships to support the implementation of social innovation (to develop new skills, knowledge and expertise), they appear to lack the necessary expertise to utilize these linkages effectively; rather, they look to partners to support them during this process. With respect to social innovation, once an opportunity has been identified, it is not clear that social enterprises have the capabilities to implement in the manner that will enable them to provide greater social benefit. Consequently, while social enterprises place 
emphasis on building relationships to work with stakeholders to develop new capabilities, this does not always translate into higher levels of social innovation.

In considering our interviews and results, we examined the extent to which stakeholder relationships lead to innovation driven from within the social enterprise or in connection with others, i.e., a reliance on others for social innovation. In Table 5, we capture the implications drawn from our study for the effect of opportunity identification and for implementation in terms of the more nuanced findings about the importance of working with or through partners rather than in isolation.

Table 5 highlights several important insights for social enterprises. First, our findings reflect the important role performed by opportunity identification relationships. Not only do those relationships help identify social innovation opportunities, as noted previously, but they are most strongly associated with the innovation arising either from social enterprises working with partners or innovation from work conducted through partners. This first result is consistent with our interpretation of the opportunity identification function in which the social enterprise's stakeholder relationships enable it to utilize its existing capabilities. The second result indicates a brokerage role being performed by the social enterprise as it is works through partners to implement the social innovation.

We find that the implementation relationships used to develop skills, knowledge and expertise, do not result in innovation when the social enterprise attempts to innovate primarily by acting alone compared to either working with or through others. This supports the idea that social enterprises are too resource-constrained to adequately develop their capabilities to effectively implement social innovation that requires different or more resources. Our interviews and results point to a failure of the "lone" social enterprise to implement social innovation. Instead, we find

Table 5 Mapping stakeholder relationships to social innovation process

\begin{tabular}{|c|c|c|c|}
\hline \multirow{2}{*}{$\begin{array}{l}\text { Relationship } \\
\text { Dimension }\end{array}$} & \multicolumn{3}{|c|}{ Implications of collaboration for social innovation } \\
\hline & Mainly by social enterprises alone & $\begin{array}{l}\text { Combination of social enterprises with } \\
\text { partners }\end{array}$ & Mainly through partners \\
\hline \multirow[t]{2}{*}{$\begin{array}{l}\text { Opportunity } \\
\text { Identification }\end{array}$} & $\begin{array}{l}\text { Investing in building social enterprise } \\
\text { Opportunity Identification } \\
\text { relationships does not help create } \\
\text { social innovation when working in } \\
\text { isolation from others }\end{array}$ & $\begin{array}{l}\text { Investing in building social enterprise } \\
\text { Opportunity Identification } \\
\text { relationships will help create social } \\
\text { innovation when working closely with } \\
\text { partners, rather than trying to do it } \\
\text { alone }\end{array}$ & $\begin{array}{l}\text { Investing in building social enterprise } \\
\text { Opportunity Identification } \\
\text { relationships will help create social } \\
\text { innovation primarily when most of the } \\
\text { innovation is being undertaken } \\
\text { through partners }\end{array}$ \\
\hline & & $\begin{array}{l}\text { Organizations can create collaborative } \\
\text { approaches with partners to enhance } \\
\text { their ability to identify opportunities } \\
\text { for social innovation. However, while } \\
\text { social enterprises will make a } \\
\text { significant contribution to social } \\
\text { innovation within these partnerships, } \\
\text { the effect is not quite as large as it is if } \\
\text { they work through others to deliver it }\end{array}$ & $\begin{array}{l}\text { To create the biggest effect for social } \\
\text { innovation, social enterprise should } \\
\text { seek to build relationships with } \\
\text { partners to develop opportunities or } \\
\text { with those that have the resources to } \\
\text { deliver on that innovation. In this role, } \\
\text { an organization's stakeholder } \\
\text { relationships can provide opportunities } \\
\text { to act as a "social innovation } \\
\text { broker"-identifying opportunities } \\
\text { and finding resources to meet those } \\
\text { needs }\end{array}$ \\
\hline \multirow[t]{2}{*}{ Implementation } & $\begin{array}{l}\text { Investing in building social enterprise } \\
\text { Implementation relationships does not } \\
\text { help build internal capabilities in a } \\
\text { manner that enables them to undertake } \\
\text { social innovation in isolation from } \\
\text { others }\end{array}$ & $\begin{array}{l}\text { Investing in building social enterprise } \\
\text { Implementation relationships with } \\
\text { others to directly enhance capabilities } \\
\text { will help create social innovation only } \\
\text { when working closely with others to } \\
\text { achieve a learning effect }\end{array}$ & $\begin{array}{l}\text { Investing in building social enterprise } \\
\text { Implementation relationships with } \\
\text { others to directly enhance capabilities } \\
\text { will help create social innovation } \\
\text { through partners-but is no different } \\
\text { than working with partners }\end{array}$ \\
\hline & $\begin{array}{l}\text { Efforts to "go-it-alone" are likely to } \\
\text { backfire as organizations do not have } \\
\text { the ability to build their resources to } \\
\text { deliver social innovation in isolation }\end{array}$ & $\begin{array}{l}\text { Organizations can create collaborative } \\
\text { learning with partners to augment their } \\
\text { innovation potential }\end{array}$ & $\begin{array}{l}\text { A social enterprise has to make the } \\
\text { decision about whether to focus on its } \\
\text { role as a "social innovation broker" } \\
\text { through developing its "Opportunity } \\
\text { Identification" relationship activities, } \\
\text { or whether it can also build its } \\
\text { implementation competencies to } \\
\text { become a "social innovation } \\
\text { transformer" }\end{array}$ \\
\hline
\end{tabular}


that implementation relationships are more effective in creating innovation when working in partnership with others. This suggests that a capability for social enterprises is that of identifying and managing stakeholder relationships rather than developing its own operations to deliver the innovation in isolation. This finding supports Bridoux and Stoelhorst's (2016) call to identify jointness of interests with stakeholders as a route through which value (in our case social innovation) can be created.

Overall, our study highlights the importance of stakeholder relationships to help organizations overcome constraints and to support the social innovation process by enabling access to resources and deploying capabilities in an effective manner to "develop opportunities for mutual benefit" recommended by Post et al. (2002, p. 23). These interactions can be both formal and informal and support the flow of knowledge between organizations. Many of our interviewees commented on how they have developed informal stakeholder relationships that resonates with Post et al.'s (2002, p. 22) observation that not only should stakeholder management be seen as a core competence but that this should be "an integral part of the culture of the organization," witnessed in our study through the myriad of individual relationships between members of the social enterprise and its stakeholders.

Our work demonstrates the imperative of clearly identifying and specifying the expectations for their relationship-building activities. While stakeholders are expected to be part of the social innovation process, it appears this is more easily accomplished when the stakeholders share common interests and goals. For example, our interviewees discussed how they collaborate more readily with community groups and other social enterprises but that greater effort is often required to develop relationships with corporations. Our work supports Bridoux and Stoelhorst's (2016) view that relationships based on altruistic alignment are a potentially greater source of joint value creation than those based on other relational motives. Likewise, Freeman et al. (2010) argue that competitionbased discourse is counterproductive to developing meaningful long-term stakeholder relationships that can contribute to value creation. With this in mind, the problem for social enterprises becomes one of how to trigger stakeholder involvement in the social innovation process. Given the constraints under which social enterprises in particular operate, combined with the hybrid organizational duality of seeking to operate under commercial practices while delivering social value, these organizations appear to have a choice: Do you become a "social innovation broker" or is your role as "social innovation deliverer"? Very few will have the ability to perform both roles effectively while going it alone appears to be the least effective route.
We develop these ideas by proposing a matrix that provides insight to managers regarding the options that appear to face them. Taking the two components of the innovation process ("opportunity identification" and "implementation") and understanding that they perform different functions for the social enterprise, we propose four distinct stakeholder relationship approaches, as shown in Fig. 1 in what we term the "Social Innovation-Stakeholder Relationship Matrix." By attending to the matrix, social enterprises will be able to clearly assess their current position and evaluate their stance relative to their desired approach to managing stakeholder relationships for social innovation.

The Broker performs an important role in the context of social innovation-identifying opportunities to fill unmet social needs. The broker does not seek to capture resources to build its own capabilities. Instead, having an outward facing agenda for action, the broker is more concerned with identifying opportunities that can either be fulfilled with its existing resources or that can be addressed by other agents.

In essence the broker may play two roles-efficiency seeking to effectively use its own capabilities and altruistic search to fulfill societal needs. In the latter role, the broker develops capabilities to engage with and seek resources from a wide range of potential stakeholders such as private, public or other third-sector agents. Agility to identify potential opportunities is critical for them and their ability to connect with and persuade these stakeholders of the veracity of the social need is paramount to their success and continued legitimacy. Social Innovation Exchange and Ideo.org are pertinent examples of organizations promoting the spread of social innovations through aiding the development of the right connections. ${ }^{1}$

The Augmenter is mainly concerned with fostering relationships that enhance its capabilities. The emphasis here is on developing new skills, building expertise, and accessing new knowledge geared to increasing the amount of social innovation that can be delivered. Social enterprises that fall into this category are often well linked to their local communities and intimately understand the opportunities for social innovation. They are, however, cognizant of their inability to build their operations and are engaged in active search with stakeholders to complement and develop their ability to deliver social innovation. For example, Honey Care Africa (Hart and London 2005) has built relationships that draw on private sector marketing capabilities and the development sector's access to social capital and microfinance to meet the local community's desire of retaining and building its domestic honey market,

\footnotetext{
${ }^{1}$ For case study, exemplars visit http://www.ideo.org/projects/history and http://www.socialinnovationexchange.org/about\#about.
} 
Fig. 1 Social InnovationStakeholder Relationship Matrix

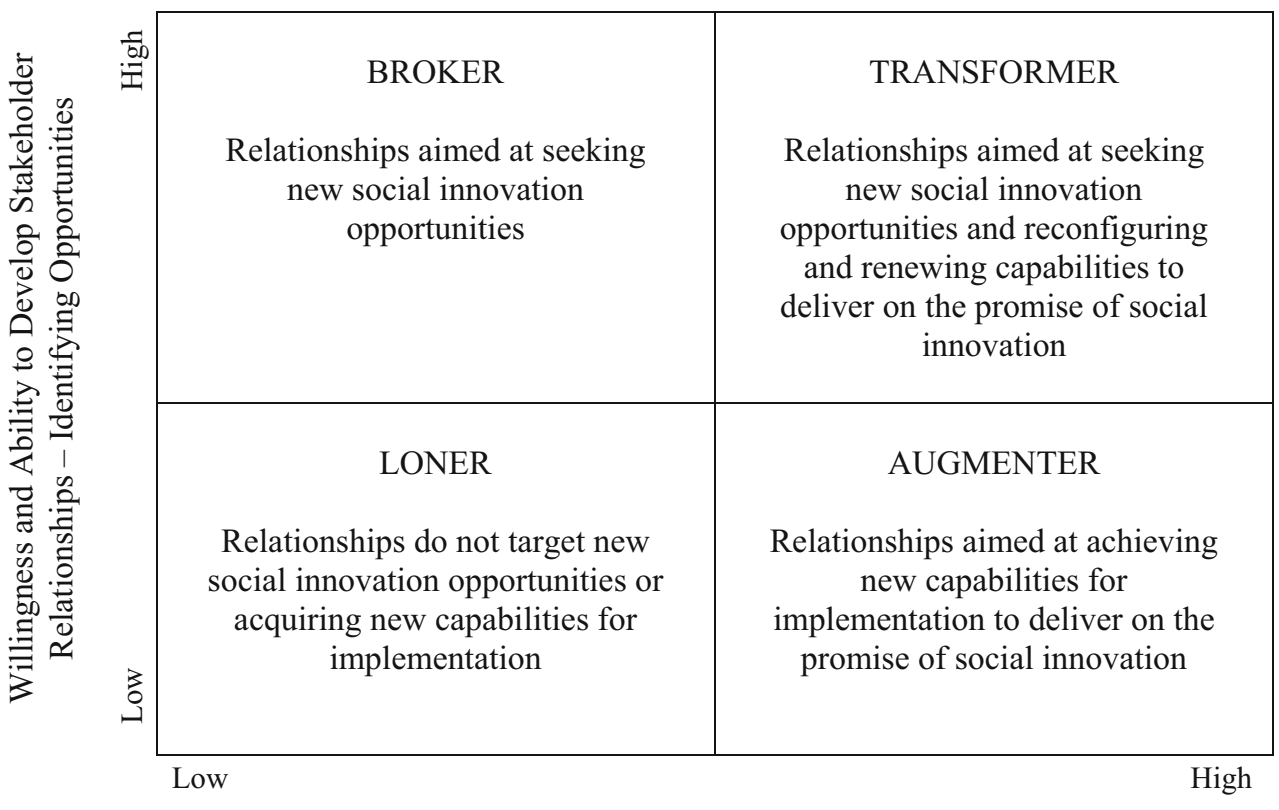

Willingness and Ability to Develop Stakeholder Relationships - Implementation resulting in more sustainable farms and rural communities in Kenya.

Since the outcome of the search process is about supplementing and strengthening knowledge and skills, the augmenter needs to develop long-term and deep relationships with its stakeholders to enable successful knowledge transfer. Such relationships will be difficult to develop, but a hallmark of the augmenter is to build trust and demonstrate commitment. For the augmenter, identifying the right partner is a critical challenge that requires active engagement across networks in search of a wide range of stakeholders that may have the capacity to assist. However, constrained by the ability to pay, augmenters will also seek to build relationships where they can expect low- or nocost benefits and will be adept at capturing externalities.

The Transformer is a pinnacle among social enterprises. Not only are these social enterprises actively and effectively engaging in a search for opportunities, they are able to manage the dual tasks of the innovation process by seamlessly yet energetically creating value from their networks. They use stakeholder relationships to both identify opportunities and implement social innovation. By combining both sets of innovation tasks, the transformer is able to capitalize upon changes in the environment more easily, being a front-runner in identifying opportunities, as well as developing relationships for skill and knowledge enhancement. Hence, the transformer is likely to have welldeveloped capabilities to connect and promote with a wide range of stakeholders, acting somewhat as a catalyst to generate resources as well as an advocate for unmet social needs. As a transformer, the social enterprise is a dynamo using the power of its stakeholder relationships to create a sense of new energy and urgency around solving social needs in new innovative ways.

The Big Issue is an example of how, through social innovation, social enterprises can transform society. Set up in 1991, The Big Issue was offered as an alternative newspaper that enables the homeless to earn an income through buying and selling copies of the paper for a profit. Through additional support from The Big Issue Foundation, sellers can access health care and support, providing a route out of homelessness and back into the community. ${ }^{2}$

The Loner represents a category of social enterprises that lack the resources or mindsets to build stakeholder relationships to either identify new opportunities or develop their capabilities to implement social innovation. Such a position is likely to be untenable in the long run and ultimately they run the risk of becoming dinosaurs-much like the unresponsive public sector bodies that many social enterprises have come to replace-and then face extinction. In short, the loner appears to be the antithesis of a successful social enterprise having all the hallmarks of an organization that appears cutoff from its community and not engaged with stakeholders. It is unclear how such organizations are likely to contribute social value in the longer term, and hence, their raison d'être is questionable. Further, without effectively building relationships that enable them to build their operations loners are consigned to increasing marginalization.

\footnotetext{
${ }^{2}$ See more at: http://www.nesta.org.uk/news/everyday-social-innova tions/big-issue.
} 
The Booker-Christie Newark reform initiative epitomizes the loner approach. Launched in 2010 by the governor of New Jersey, mayor of Newark and Mark Zuckerberg, the social venture aimed to bring \$200 million investment into Newark's educational system. However, a top-down approach led by external parties from outside Newark, coupled by an inability to engage with local stakeholders, resulted in a project that did not meet the needs of the community nor addressed real issues inherent to Newark's education system and "instead of unifying Newark residents behind a shared goal, the BookerChristie initiative polarized the city" (Barnes and Schmitz 2016, p. 32). The strength of local opposition forced the venture to be abandoned in 2014 .

Social enterprises that find themselves falling into a loner trap need to consider what their function in society is - and may need to ask whether they are truly meeting a unique or unmet social need. For those that are committed to their social mission, loners face an uphill task in seeking to develop their stakeholder networks and make the transition to one of the other types. If the social enterprise languishes and fails to achieve its potential in the "loner" mode, the social enterprise may need to reconsider whether it is truly addressing a social issue that it is contributing toward solving a problem. As the Booker-Christie example highlights, for social innovation to work, the voices of the marginal stakeholders must be heard as opposed to those emanating from the most powerful stakeholders. In such a situation, issue-focused stakeholder (Roloff 2008) management may be appropriate, alleviating the negative impact of overlooking marginalized societal groups and ensuring "solution fit."

\section{Conclusions}

Social enterprises are reliant on a range of different types of stakeholder relationship to support them through the social innovation process, but it is at the implementation phase that social enterprises are most in need of support, requiring help in building capabilities through cooperation. Through these linkages, social enterprises should be able to adapt and configure their capabilities to develop social innovation, despite changes in resource availability. Such interactions emphasize the need for social enterprises to manage their stakeholder relationship-building capabilities as social enterprises are constantly required to integrate, reconfigure, renew and recreate their resources and capabilities in response to the changing social landscape and fluctuating resource base.

Social enterprises are capable of identifying opportunities and operating on a small scale, but the next step of broadening the potential for social innovation and delivering social benefits requires them to effectively develop relationships with stakeholders through which to enhance capabilities. The lessons learned from our research can help inform a range of organizations on the nature and type of relationships they need to embrace to develop the capabilities required to produce social innovations that deliver the benefits envisaged. Both mainstream organizations and social enterprises can benefit from working together. Social enterprises are often better placed and more able to identify and appreciate the notion of social innovation while the business acumen that lies within companies can be useful to those social enterprises lacking the skills to develop their ideas and see them come to fruition. Consequently, cooperating with social enterprises can provide mechanisms through which large companies can effectively engage with their social environments in furthering their commitments to society (Post et al. 2002).

The focus of this research in the UK may raise questions of generalizability to the rest of the world; however, there are significant advantages of restricting the scope of the study to one country context. While cross-country comparative studies potentially allow for generating generalizable theory, such studies involve differences in social policy contexts and legal frameworks that are not the specific focus of the paper. Moreover, the UK policy context is an interesting one in which to observe the phenomenon of social innovation in the same manner that Scandinavia provides insight into stakeholder-based cooperative advantage (Strand and Freeman 2015). Following the notion of the Big Society, government policy has acknowledged social enterprises as a new legal form and subsequently created an expectation that social innovation is to be taken up by social enterprises. In contrast, particularly in the USA, much of the social innovation agenda tends to focus on conventional firms as part of their CSR programs. Due to the policy context and because there has been little prior research on UK social enterprises, this is an appropriate focus for this study.

This paper presents a proposed social innovationstakeholder relationship matrix that provides managers with insight to their organizational capabilities for achieving their social innovation missions. Building upon the study, further research could be undertaken to investigate the role of institutional support, such as from universities and research institutions and to explore the institutional processes and logics prevalent that both constrain, and support the capture of social innovation opportunities. Additional research into linkages with private sector firms and CSR activities could bring insight into the mechanisms of cross-sector collaboration. Relatedly, the matrix suggests the most effective social innovation will accrue from those social enterprises that embrace a 
new networking approach. Further work can examine the process of change within social enterprises to achieve this.

Likewise, while our study has identified networking as a critical capability, we did not examine the potential promise and issues inherent in network governance but believe this could be an area for future work. In particular, communities of practice (CoP) theory as proposed by Lave and Wenger (1991) could be usefully employed as an analytical framework in developing an understanding of how "governance" is conducted within stakeholder networks involved in social innovation. Recently, globalization has seen the advent of global public policy issues, involving a range of different heterogeneous actors struggling to meet conflicting contradictory societal requirements. Future studies could look at Global Action Networks (Waddell 2003) and emerging multi-stakeholder networks addressing global issues and their role in the process of social innovation.

Finally, our research highlights that stakeholder management is a complex and messy process in organizations such as social enterprises for which there is no easy solution and for which our matrix aims to provide broad guidance on strategic direction.

\section{Compliance with Ethical Standards}

Conflict of interest The authors declare that they have no conflict of interest.

Ethical Approval All procedures performed in studies involving human participants were in accordance with the ethical standards of the institutional and/or national research committee and with the 1964 Declaration of Helsinki and its later amendments or comparable ethical standards.

Animal Rights Statement This article does not contain any studies with animals performed by any of the authors.

Informed Consent Informed consent was obtained from all individual participants included in the study.

Open Access This article is distributed under the terms of the Creative Commons Attribution 4.0 International License (http://crea tivecommons.org/licenses/by/4.0/), which permits unrestricted use, distribution, and reproduction in any medium, provided you give appropriate credit to the original author(s) and the source, provide a link to the Creative Commons license, and indicate if changes were made.

\section{References}

Alter, K. (2007). Social enterprise typology. Virtue Ventures LLC. Retrieved September 21, 2015 from http://www.virtueventures. com/resources/setypology.

Barnes, M., \& Schmitz, P. (2016). Community engagement matters (now more than ever). Stanford Social Innovation Review, 14(2), 32-39.
Battilana, J., \& Dorado, S. (2010). Building sustainable hybrid organizations: The case of commercial microfinance organization. Academy of Management Journal, 53, 1410-1440.

Battilana, J., Lee, M., Walker, J., \& Dorsey, C. (2012). In search of the hybrid ideal. Stanford Social Innovation Review, 12, $51-55$.

Belsley, D. A. (1991). Conditioning diagnostics: Collinearity and weak data in regression. New York: Wiley.

Bessant, J. (2003). Challenges in innovation management. In L. V. Shavinina (Ed.), International handbook on innovation (pp. 761-774). Oxford: Elsevier.

Birkinshaw, J., Bessant, J., \& Delbridge, R. (2007). Finding, forming, and performing: Creating networks for discontinuous innovation. California Management Review, 49(3), 67-84.

BIS. (2011). A guide to legal forms for social enterprise. London: Department for Business, Innovation and Skills.

Booz Allen \& Hamilton, Inc. (1982). New products management for the 1980s. New York: Booz Allen \& Hamilton.

Bridoux, F., \& Stoelhorst, J. W. (2016). Stakeholder relationships and social welfare: A behavioral theory of contributions to joint value creation. Academy of Management Review, 41(2), 229-251.

Cajaiba-Santana, G. (2014). Social innovation: Moving the field forward. A conceptual framework. Technological Forecasting and Social Change, 82, 42-51.

Chalmers, D. (2013). Social innovation: an exploration of the barriers faced by innovating organisations in the social economy. Local Economy, 28(1), 17-34.

Chalmers, D. M., \& Balan-Vnuk, E. (2013). Innovating not-for-profit social ventures: Exploring the microfoundations of internal and external absorptive capacity routines. International Small Business Journal, 31(7), 785-810.

Chell, E. (2007). Social enterprise and entrepreneurship: Towards a convergent theory of the entrepreneurial process. International Small Business Journal, 25(5), 5-26.

Chesbrough, H. (2003). Open innovation: The new imperative for creating and profiting from technology. Boston, MA: Harvard Business School Press.

Chesbrough, H., Vanhaverbeke, W., \& West, J. (Eds.). (2006). Open innovation: Researching a new paradigm. Oxford: Oxford University Press.

Dahan, N. M., Doh, J. P., Oetzel, J., \& Yaziji, M. (2010). CorporateNGO collaboration: Co-creating new business models for developing markets. Long Range Planning, 43, 326-342.

De Bruin, A. M., \& Ferrante, F. M. (2011). Bounded opportunity: A knowledge-based approach to opportunity recognition and development. Entrepreneurship Research Journal, 1(4), 1-21.

Dees, J. G. (2008). Philanthropy and enterprise: Harnessing the power of business and social entrepreneurship for development. Innovations: Technology, Governance \& Globalization, 3(3), 119-132.

Dees, J. G., \& Anderson, B. B. (2006). Framing a theory of social entrepreneurship: Building on two schools of practice and thought. Research on Social Entrepreneurship ARNOVA Occasional Paper Series, 1(3), 39-66.

Ducci, G., Stentella, C., \& Vulterini, P. (2002). The social enterprise in Europe: The state of the art. International Journal of Mental Health, 31(3), 76-91.

Dyer, J. H., \& Singh, H. (1998). The relational view: Cooperative strategy and sources of inter-organizational competitive advantage. Academy of Management Review, 23, 660-679.

Edwards-Schachter, M. E., Matti, C. E., \& Alcántara, E. (2012). Fostering quality of life through social innovation: A living lab methodology study case. Review of Policy Research, 29(6), 672-692. 
Emerson, J., \& Twersky, F. (Eds.). (1996). New social entrepreneurs: The success, challenge, and lessons of non-profit enterprise creation. Roberts Foundation: San Francisco.

EU. (2014). Social innovation: A decade of changes. Luxembourg: Publications Office of the European Union.

Field, A. (2009). Discovering statistics using SPSS. London: Sage Publications.

Freeman, R. E., Harrison, J. S., Wicks, A. C., Parmar, B., \& de Colle, S. (2010). Stakeholder theory. The state of the art. Cambridge: Cambridge University Press.

Garriga, E. (2014). Beyond stakeholder utility function: Stakeholder capability in the value creation process. Journal of Business Ethics, 120, 489-507.

Hair, J. F., Anderson, R. E., Tatham, R., \& Black, W. C. (1998). Multivariate data analysis. Upper Saddle River, NJ: Prentice Hall.

Hart, S. L., \& London, T. (2005). Developing native capability: What multinational corporations can learn from the base of the pyramid. Stanford Social Innovation Review, 3(2), 28-33.

Hung, K.-P., \& Chou, C. (2013). The impact of open innovation on firm performance: The moderating effects of internal R\&D and environmental turbulence. Technovation, 33(10-11), 368-380.

Lave, J., \& Wenger, E. (1991). Situated learning: Legitimate peripheral participation. New York: Cambridge University Press.

Lettice, F., \& Parekh, M. (2010). The social innovation process: Themes, challenges and implications for practice. International Journal of Technology Management, 51, 139-158.

Lyon, F. (2012). Social innovation, co-operation, and competition: Inter-organizational relations for social enterprises in the delivery of public services. In A. Nicholls \& A. Murdock (Eds.), Social innovation (pp. 139-161). London: Palgrave Macmillan.

Lyon, F., \& Fernandez, F. (2012). Strategies for scaling up social enterprise: Lessons from early years providers. Social Enterprise Journal, 8(1), 63-77.

Manning, S., \& Roessler, D. (2014). The formation of cross-sector development partnerships: How bridging agents shape project agendas and longer-term alliances. Journal of Business Ethics, 123, 527-547.

Meulman, J., \& Heiser, W. J. (2011). SPSS categories 20. Somers, NY: IBM Corporation.

Monllor, J., \& Attaran, S. (2008). Opportunity recognition of social entrepreneurs: An application of the creativity model. International Journal of Entrepreneurship and Small Business, 6(1), $54-67$.

Moore, M., Westley, F. R., \& Nicholls, A. (2012). The social finance and social innovation nexus. Journal of Social Entrepreneurship, $3(2), 115-132$.

Mulgan, G. (2006). The process of social innovation. Innovations: Technology, Governance \& Globalization, 1(2), 145-162.

Murphy, P. J., \& Coombes, S. M. (2009). A model of social entrepreneurial discovery. Journal of Business Ethics, 87, 325-336.

Murray, R., Caulier-Grice, J., \& Mulgan, G. (2009). Social venturing. The social innovator series. London: NESTA.

Nicholls, A., \& Huybrechts, B. (2016). Sustaining inter-organizational relationships across institutional logics and power asymmetries: The case of Fair Trade. Journal of Business Ethics, 135, 699-714.

Nicholls, A., \& Murdock, A. (2012). Social innovation. Basingstoke: Palgrave Macmillan.

OECD. (2011). Fostering social innovation to address social challenges. Workshop Proceedings, OECD. Retrieved September 21, 2015 from https://www.oecd.org/sti/inno/47861327.pdf.

Phillips, W., Lee, H., James, P., Ghobadian, A., \& O'Regan, N. (2015). Social innovation and social entrepreneurship: A systematic review. Group and Organization Management, 40(3), 428-461.

Phillips, S. D., \& Smith, S. R. (2014). A dawn of convergence? Third sector policy regimes in the 'Anglo-Saxon' cluster. Public Management Review, 16(8), 1141-1163.

Phills, J. A., Deiglmeier, K., \& Miller, D. T. (2008). Rediscovering social innovation. Stanford Social Innovation Review, 6(4), $34-43$.

Post, J. E., Preston, L. E., \& Sachs, S. (2002). Managing the extended enterprise: The new stakeholder view. California Management Review, 45(1), 6-28.

Roloff, J. (2008). Learning from multi-stakeholder networks: Issuefocussed stakeholder management. Journal of Business Ethics, 82(1), 233-250

Mulgan, G. Tucker, S. Ali, R., \& Sanders, B. (2007). Social innovation: What it is, why it matters, how it can be accelerated. Working Paper, Skoll Centre for Social Entrepreneurship, University of Oxford, Oxford.

Seelos, C., \& Mair, J. (2007). Profitable business models and market creation in the context of deep poverty: A strategic view. Academy of Management Perspectives, 21, 49-63.

Social Enterprise UK. (2015). The state of social enterprise survey 2015. London: Social Enterprise UK.

Strand, R., \& Freeman, R. E. (2015). Scandinavian cooperative advantage: The theory and practice of stakeholder engagement in Scandinavia. Journal of Business Ethics, 127, 65-85.

van der Have, R. P., \& Rubalcaba, L. (2016). Social innovation research: An emerging area of innovation studies? Research Policy, 45(9), 1923-1935.

Waddell, S. (2003). Global action networks. Journal for Corporate Citizenship, 12, 1-16.

West, J., \& Bogers, M. (2014). Leveraging external sources of innovation: A review of research on open innovation. Journal of Product Innovation Management, 31(4), 814-831.

Westley, F., Antadze, N., Riddell, D. J., Robinson, K., \& Geobey, S. (2014). Five configurations for scaling up social innovation: Case examples of nonprofit organizations from Canada. The Journal of Applied Behavioral Science, 50(3), 234-260.

Williams, W., \& Lewis, D. (2005). Convergent interviewing: A tool for strategic investigation. Strategic Change, 14, 219-229.

Zott, C., \& Amit, R. (2007). Business model design and the performance of entrepreneurial firms. Organization Science, 18(2), 181-199.

Zott, C., Amit, R., \& Massa, L. (2011). The business model: Recent developments and future research. Journal of Management, 37(4), 1019-1042. 